\title{
Biological Properties of Recombinant Human Monocyte-derived Interleukin 1 Receptor Antagonist
}

\author{
William P. Arend, ${ }^{*}$ Howard G. Welgus, ${ }^{\ddagger}$ Robert C. Thompson, ${ }^{5}$ and Stephen P. Eisenberg \\ *Division of Rheumatology, Department of Medicine, University of Colorado Health Sciences Center, Denver, \\ Colorado 80262; ${ }^{\ddagger}$ Division of Dermatology, Department of Medicine, Jewish Hospital at Washington \\ University Medical Center, St. Louis, Missouri 63110; and ${ }^{\S}$ Synergen, Inc., Boulder, Colorado 80301
}

\begin{abstract}
Human monocytes cultured on adherent IgG produce a specific IL-1 inhibitor that functions as a receptor antagonist (IL-1 ra). This molecule has been purified, sequenced, cloned as a cDNA, and expressed in Escherichia coli. Recombinant IL-1 ra has 17,000 mol wt and binds to IL-1 receptors on T lymphocytes, synovial cells, and chondrocytes with an affinity nearly equal to that of IL-1. These studies have examined some biological properties of purified recombinant human IL-1 ra. This protein exhibits a dose-responsive inhibition of IL-1 $\alpha$ and IL-1 $\beta$ augmentation of PHA-induced murine thymocyte proliferation. The recombinant IL-1 ra also blocks IL-1 $\alpha$ and IL-1 $\beta$ stimulation of $\mathrm{PGE}_{2}$ production in human synovial cells and rabbit articular chondrocytes, and of collagenase production by the synovial cells. A $50 \%$ inhibition of these IL-1-induced biological responses requires amounts of $I L-1$ ra up to 100 -fold in excess of the amounts of IL-1 $\alpha$ or IL-1 $\beta$ present. IL-1ra may play an important role in normal physiology or in pathophysiological states by functioning as a natural IL-1 receptor antagonist in the cell microenvironment. (J. Clin. Invest. 1990. 85:1694-1697.) interleukin $1 \bullet$ interleukin 1 receptor • monocytes
\end{abstract}

\section{Introduction}

IL-1 has numerous effects on both immune and inflammatory cells, including augmentation of $\mathrm{T}$ and $\mathrm{B}$ lymphocyte function (1). In addition, IL-1 may be a mediator of tissue destruction in chronic autoimmune or inflammatory diseases. These diseases include juvenile-onset diabetes mellitus, where IL-1 may directly or indirectly induce toxicity to $\beta$ cells in the islets of Langerhans (2). In rheumatoid arthritis IL-1 may contribute to joint damage through stimulating $\mathrm{PGE}_{2}$ and collagenase production in synovial fibroblasts and chondrocytes (3).

Because of the pleiotropic effects of IL-1 on many different target cells, and purported roles in normal physiology and in pathophysiology, it has been hypothesized that natural inhibitors of IL-1 might exist (4). IL-1 inhibitory activities have been

Address reprint requests to Dr. Arend, Box B-115, University of Colorado Health Sciences Center, 4200 East Ninth Avenue, Denver, CO 80262.

Received for publication 3 January 1990 and in revised form 14 February 1990.

J. Clin. Invest.

(C) The American Society for Clinical Investigation, Inc.

0021-9738/90/05/1694/07 \$2.00

Volume 85, May 1990, 1694-1697 described in human body fluids and in the supernatants of cultured human or animal cells or cell lines (reviewed in Arend et al. [5]). In most cases, these biological activities have not been further characterized and their mechanisms of action have not been determined. However, IL-1 inhibitors could be acting at multiple levels; these include decreasing synthesis and release of IL-1, adhering to IL-1 in solution, blocking IL-1 receptor binding, or interfering with IL-1-induced signal transduction at a post-receptor level. For example, the ubiquitous urinary protein uromodulin binds to IL-1 in solution (6) and deoxyribonuclease I from human urine interferes with detection of IL-1 in the thymocyte assay, possibly by releasing free thymidine (7).

An IL-1 inhibitory activity has been described in the supernatants of human monocytes cultured on adherent IgG or immune complexes $(5,8)$ and in the urine of patients with fever or myelomonocytic leukemia (9-11). This specific IL-1 inhibitor of 22,000 mol wt blocks the binding of IL- $1 \alpha$ or IL- $1 \beta$ to IL- 1 receptors on the murine thymoma cell line EL4-6.1 $(5,11)$. In recent studies this monocyte-derived molecule has been purified and partially sequenced (12). This native molecule represents a unique new protein that exists in two forms, a 22,000-mol wt glycosylated form with some microheterogeneity, and an nonglycosylated 17,000-mol wt form. A complementary DNA has been cloned and expressed in Escherichia coli with production of recombinant 17,000mol wt molecules (13). Similar to the crude or semipurified IL-1 inhibitor, the recombinant molecule blocks IL-1 binding to the IL-1 receptor on EL4-6.1 cells $(5,11,12)$. Furthermore, this molecule has no detectable IL-1 agonist effects on human foreskin fibroblasts and therefore functions as an IL-1 receptor antagonist (IL-1 ra) ${ }^{1}(5,10,12)$. The results of studies on biological properties of purified recombinant 17,000-mol wt IL-1 ra are reported in this paper.

\section{Methods}

Recombinant IL-1ra. Expression of IL-1 ra in Escherichia coli was carried out as recently described (13). The recombinant IL-1 ra of $17,000 \mathrm{~mol} w \mathrm{w}$ was purified from the bacterial lysates by successive cation and anion-exchange column chromatography. The IL-1 ra was $>95 \%$ pure as determined by silver staining after SDS-PAGE. The IL-1 ra protein concentration was determined by $\mathrm{OD}_{280}$ using a calculated extinction coefficient of $0.776(\mathrm{mg} / \mathrm{ml})^{-1}$. The recombinant IL-1 ra was stored at $-70^{\circ} \mathrm{C}$ in small aliquots in PBS with $10 \%$ glycerol.

1. Abbreviation used in this paper: IL-1 ra, interleukin 1 receptor antagonist. 
A fresh aliquot was thawed for each experiment. Stored in this fashion for up to $6 \mathrm{mo}$, the recombinant IL-1 ra demonstrated a full maintenance of biological activities.

Effects of IL-1ra on thymocyte proliferation. The recombinant IL-1 ra was assayed against IL- $1 \alpha$ or $-\beta$ augmentation of PHA-induced proliferation of thymocytes from $\mathrm{C} 3 \mathrm{H} / \mathrm{HeJ}$ mice, as recently described (5). Recombinant human IL-1 $\alpha$ (compliments of Dr. Peter T. Lomedico, Hoffmann-La Roche, Inc., Nutley, NJ) and recombinant human IL-1 $\beta$ (compliments of Dr. John Childs, Synergen, Inc., Boulder, CO) were used at baseline concentrations of $56 \mathrm{pg} / \mathrm{ml} \mathrm{IL-1} \alpha$ and $207 \mathrm{pg} / \mathrm{ml}$ IL- $1 \beta$, respectively. These concentrations were functionally equivalent to $3 \mathrm{U} / \mathrm{ml}$ of both types of IL-1, reflecting the fact that the recombinant IL- $1 \alpha$ possessed a higher specific activity than did the IL- $1 \beta$. A unit of IL-1 activity was defined as that amount giving $50 \%$ maximal augmentation in the murine thymocyte assay. A concentration of $3 \mathrm{U} / \mathrm{ml}$ of IL- $1 \alpha$ or IL- $1 \beta$ yielded $\approx 80 \%$ of maximal stimulation of thymocytes. Serial dilutions of the recombinant IL-1 ra were mixed with the single amount of IL- $1 \alpha$ or IL- $1 \beta$ before adding to the thymocytes in 96-well plates. The cells were cultured in RPMI-1640 medium (Gibco Laboratories, Grand Island, NY) with $10 \%$ low-endotoxin FCS (HyClone Laboratories, Logan, UT) for $4 \mathrm{~d}$ at $37^{\circ} \mathrm{C}$ and $5 \% \mathrm{CO}_{2}$. Thymocyte proliferation was measured by the colorimetric method with 3-(4,5-dimethylthiazol-2-y1)-2,5-diphenyl tetrazolium bromide (MTT), as described $(5,14)$. Recombinant IL-1 ra also was tested against IL-2 (Amgen Biologicals, Thousand Oaks, CA) effects in the murine thymocyte assay.

Effects of IL-1ra on IL-1 stimulation of synovial cells and chondrocytes. The recombinant IL-1 ra also was assayed for inhibitory activity against IL-1 induction of biological responses in synovial cells and chondrocytes. Human synovial cells (15) and rabbit articular chondrocytes (16) were obtained and cultured adherent to plastic as recently described (5). Chondrocytes were used either in the original culture or first passage to avoid problems with dedifferentiation. Rheumatoid synovial cells were used at confluency in the first through third passage. Again, $3 \mathrm{U} / \mathrm{ml}$ of human IL- $1 \alpha$ or IL- $1 \beta$ were mixed with increasing amounts of IL-1 ra and added to the cells in DME with 5\% NuSerum (Collaborative Research, Inc., Waltham, MA). These amounts of IL- $\alpha$ and IL $-1 \beta$ yielded submaximal stimulation of the synovial cells and chondrocytes. After $16 \mathrm{~h}$ of culture at $37^{\circ} \mathrm{C}$ and $5 \% \mathrm{CO}_{2}$ supernatants were harvested for determination of $\mathrm{PGE}_{2}$ concentration by a specific ELISA (17). Initial experiments performed in the absence of any added serum indicated that $P E_{2}$ levels in cell supernatants were low and highly variable. ELISAs also were used to measure protein concentrations of latent and active collagenase (18) and tissue inhibitor of metalloproteinases (19) in supernatants of cultured rheumatoid synovial cells.

\section{Results}

Inhibition of $I L-1 \alpha$ and $I L-1 \beta$ augmentation of murine thymocyte proliferation. The recombinant IL-1 ra first was assayed against $3 \mathrm{U} / \mathrm{ml}$ IL- $\alpha$ or IL- $1 \beta$ in the murine thymocyte assay. Parallel dose-responsive inhibition curves were obtained with IL- 1 ra and either form of IL-1 (Fig. 1). 50\% inhibition of IL- $1 \alpha$ and IL- $1 \beta$ effects was observed with $\approx 2$ and $1 \mathrm{ng} / \mathrm{ml}$ IL- $1 \mathrm{ra}$, respectively. These amounts of IL-1 ra are 40 times the concentration of IL- $1 \alpha$ and 5 times the concentration of IL- $1 \beta$ used to stimulate the thymocytes. The effects of a submaximal amount of IL-2 $(10 \mathrm{U} / \mathrm{ml})$ in the thymocyte assay were not inhibited by IL-1 ra in concentrations up to $100 \mathrm{ng} / \mathrm{ml}$ (data not shown). In addition, these amounts of IL-1 ra alone exhibited no stimulatory or agonist effects on the murine thymocytes.

Inhibition of IL-1 stimulation of synovial cells and fibroblasts. The recombinant IL-1 ra also was evaluated for effects on IL-1 stimulation of adherent human synovial cells and rab-

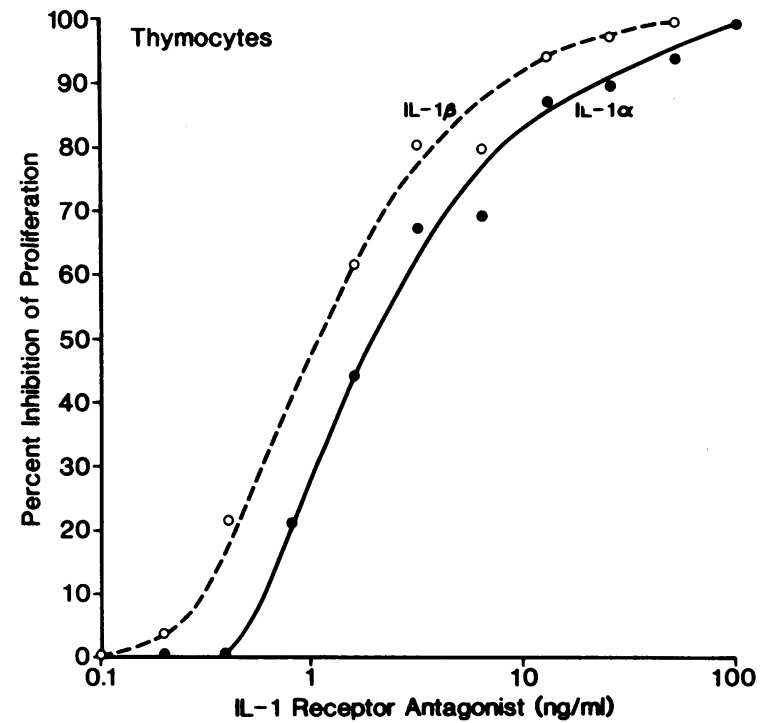

Figure 1. The effects of recombinant IL-1 ra on IL- $1 \alpha$ or IL-1 $\beta$ augmentation of PHA-induced murine thymocyte proliferation. $3 \mathrm{U} / \mathrm{ml}$ of IL- $1 \alpha(\bullet, 56 \mathrm{pg} / \mathrm{ml})$ and of IL- $1 \beta(0,207 \mathrm{pg} / \mathrm{ml})$ were combined with serially increasing concentrations of IL-1 ra, then cultured with thymocytes for $4 \mathrm{~d}$. Thymocyte proliferation was assessed by the 3-(4,5-dimethylthiazol-2-yl)-2,5-diphenyl tetrazolium bromide method. The data are expressed as percent inhibition of thymocyte proliferation, on a linear scale, vs. nanograms per milliliter IL-1 receptor antagonist on a log scale. The baseline OD $(570 \mathrm{~nm})$ for IL- $1 \alpha$ and IL- $1 \beta$ stimulation were 0.538 and 0.562 , respectively. Representative results are presented from one of five experiments.

bit articular chondrocytes. These cells were stimulated with 3 $\mathrm{U} / \mathrm{ml}$ of IL- $1 \alpha$ or IL- $1 \beta$. Examination of $\mathrm{PGE}_{2}$ production revealed similar dose-responsive inhibition curves with serial concentrations of IL-1 ra cultured with IL-1 and either synovial cells (Fig. 2) or chondrocytes (Fig. 3). In addition, the IL-1 ra inhibited IL-1 stimulation of collagenase production by the human synovial cells in a similar fashion (Fig. 4). IL-1 ra alone in concentrations up to $100 \mathrm{ng} / \mathrm{ml}$ exhibited no agonist effects on either synovial cells or chondrocytes. Unstimulated synovial cells produced large amounts of tissue inhibitor of metalloproteinases with no alterations observed with IL- $1 \alpha$ or IL- $1 \beta$ or with IL-1 ra (data not shown).

Comparison of the relative potencies of IL-1 ra against IL- $1 \alpha$ or IL- $1 \beta$ stimulation of the two cell types revealed some interesting differences. $50 \%$ inhibition of IL- $1 \alpha$ or IL- $1 \beta$ induction of $\mathrm{PGE}_{2}$ production by the synovial cells was observed with $\approx 1.6$ and $2.8 \mathrm{ng} / \mathrm{ml}$ IL-1 ra, respectively (Table 1 ). These protein concentrations were $\approx 30$ - and 10 -fold greater than the concentrations of IL- $\alpha$ or IL- $1 \beta$ used to stimulate the cells. The rabbit chondrocytes required higher amounts of IL-1 ra, 5.7 and $15.5 \mathrm{ng} / \mathrm{ml}$, respectively, to yield $50 \%$ inhibition of IL- $1 \alpha$ and IL- $1 \beta$ stimulation (Table I). These concentrations are up to 100 -fold higher than the stimulating levels of IL-1.

\section{Discussion}

The experiments reported herein examine the biological activities of purified recombinant monocyte-derived IL-1 ra, a receptor antagonist of IL-1. The results indicate that the purified recombinant IL-1 ra possesses an identical spectrum of biological activities as does the unpurified IL-1 ra in IgG-induced 


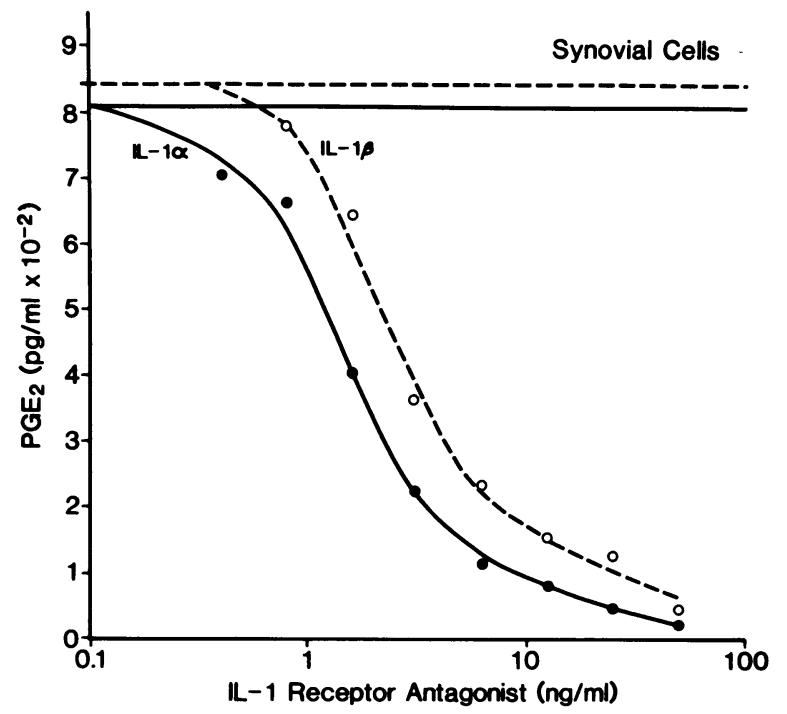

Figure 2. Inhibition of IL-1-induced $\mathrm{PGE}_{2}$ production in cultured adherent human synovial cells by recombinant IL-1 ra. Serially increasing amounts of recombinant IL-1 ra and $3 \mathrm{U} / \mathrm{ml}$ of IL- $1 \alpha(\bullet)$, or $\beta(0)$, were incubated with the cells for $16 \mathrm{~h}$. $\mathrm{PGE}_{2}$ concentrations in cell supernatants were determined by an ELISA. The data are expressed as picograms per milliliter $\mathrm{PGE}_{2}$ produced vs. nanograms per milliliter IL-1 receptor antagonist present during culture. The horizontal lines represent the baseline levels of IL-1-induced $\mathrm{PGE}_{2}$ production. Representative results are shown from one of three experiments.

monocyte supernatants (5). The recombinant IL-1 ra exhibited a dose-responsive inhibition of IL-1 effects on murine thymocytes, human synovial cells, and rabbit articular chondrocytes. The inhibition of IL-2 augmentation of murine thymocyte proliferation observed in the previous studies probably was due to another protein than IL-1 ra in the crude monocyte supernatant. This conclusion is supported by the observation that highly purified native IL-1 ra, like the recombinant mole-

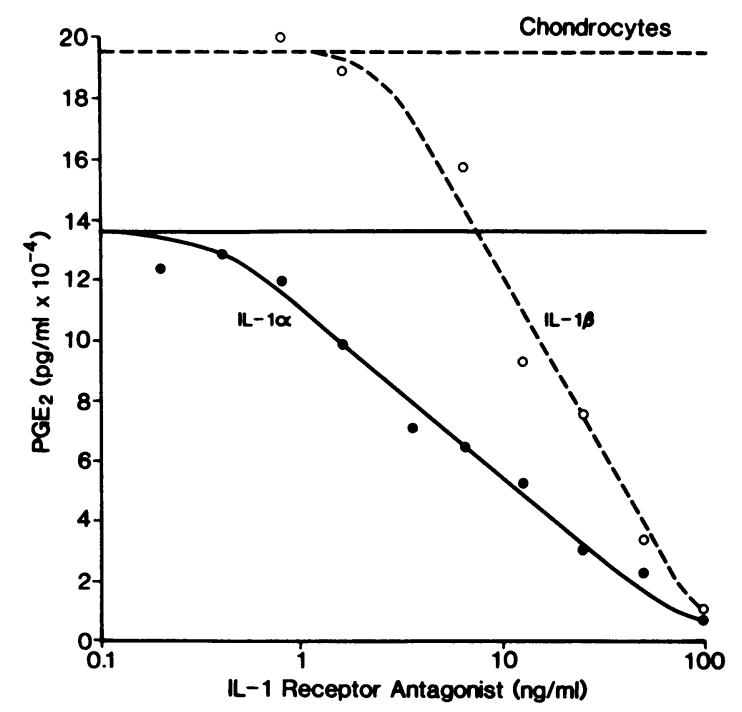

Figure 3. Inhibition of IL-1-stimulated $\mathrm{PGE}_{2}$ production in cultured adherent rabbit articular chondrocytes by recombinant IL-1 ra. The experiment was performed and the data are expressed as described in the legend for Fig. 2. Representative results are depicted from one of four experiments.

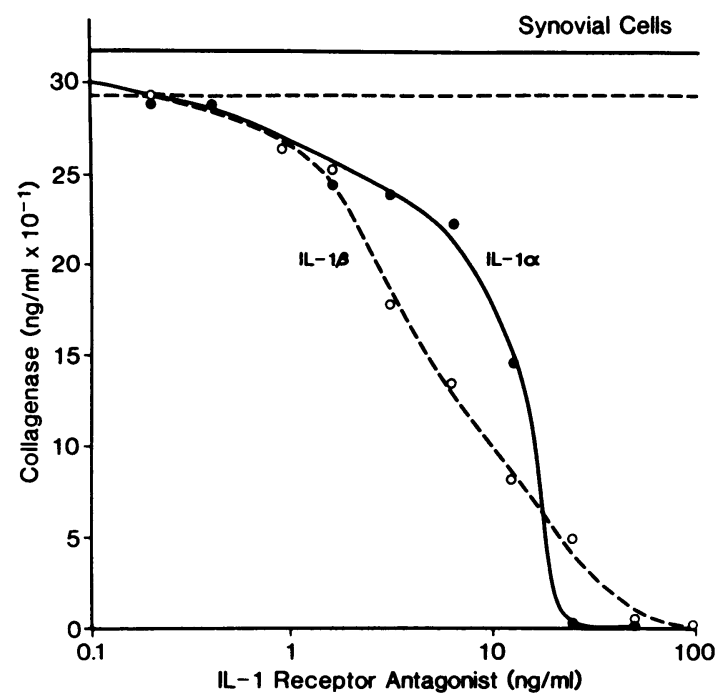

Figure 4. Inhibition of IL-1-induced collagenase production in cultured adherent human synovial cells by recombinant IL-1 ra. Collagenase concentrations in cell supernatants were determined by an ELISA. The data are expressed as nanograms per milliliter collagenase produced vs. nanograms per milliliter IL-1 receptor antagonist present during culture.

cule, does not inhibit IL-2 effects on thymocytes (Arend, W. P., and C. H. Hannum, unpublished observations).

The majority of the native monocyte-derived IL-1 ra is a 22,000 -mol wt form that is glycosylated (12). Small amounts of the nonglycosylated form of the same unique molecule $(17,000 \mathrm{~mol} \mathrm{wt})$ also are present in IgG-induced monocyte supernatants $(12,13)$. The nonglycosylated recombinant $17,000-\mathrm{mol} \mathrm{wt}$ IL-1 ra possesses an identical specific activity as the 22,000-mol wt form of the purified native molecule in the murine thymocyte assay (Arend, W. P., and C. H. Hannum, unpublished observations). Therefore, the presence of carbohydrate is not necessary for maintenance of full biological activity.

An important observation is that 5- to 100 -fold greater amounts of IL-1 ra are necessary to observe $50 \%$ inhibition of IL- $1 \alpha$ and IL- $1 \beta$ stimulation of murine thymocytes, human synovial cells, or rabbit articular chondrocytes. This result is even more striking when considering that the IL-1 ra binds to IL-1 receptors on all three cell types with nearly the same

Table I. Inhibition of IL-1-induced PGE Production by IL-1ra*

\begin{tabular}{ccc}
\hline Cell & Inducing protein & 50\% inhibition \\
\hline & & $n g / m l ~ I L-1 r a^{\ddagger}$ \\
Human synovial cells & IL-1 $\alpha$ & 1.6 \\
Rabbit chondrocytes & IL-1 $\beta$ & 2.8 \\
& IL-1 $\alpha$ & 5.7 \\
& IL-1 $\beta$ & 15.5
\end{tabular}

* Cultured human synovial cells or rabbit articular chondrocytes were incubated for $16 \mathrm{~h}$ with $3 \mathrm{U} / \mathrm{ml} \mathrm{IL-1}(56 \mathrm{pg} / \mathrm{ml} \mathrm{IL-} 1 \alpha$ and 207 $\mathrm{pg} / \mathrm{ml} \mathrm{IL}-1 \beta)$ and serially increasing concentrations of recombinant IL-1 ra. $\mathrm{PGE}_{2}$ concentrations in cell supernatants were measured using an ELISA.

₹ The concentrations of IL- 1 ra giving $50 \%$ inhibition of IL-1-induced $\mathrm{PGE}_{2}$ production were extrapolated from Figs. 2 and 3. 
affinity as IL- $1 \alpha$ or IL- $1 \beta(12) .^{2}$ An explanation for the apparent differences in IL-1 ra potency between direct binding to the IL-1 receptor and in biological activities probably lies in the fact that all these cell types are exquisitely responsive to tiny amounts of IL-1. Maximal biological responses can be observed when $<5 \%$ of available receptors are occupied by IL-1. Thus, although IL-1 ra and IL-1 bind to receptors in an equimolar fashion, much higher concentrations of IL-1 ra are necessary to block IL-1 occupancy of only a few receptors.

IL-1 ra alone exhibited no agonist effects on murine thymocytes, human synovial cells and rabbit articular chondrocytes. Furthermore, IL-1 ra blocked IL-1-induced $\mathrm{PGE}_{2}$ production by human foreskin fibroblasts (13) and adhesion molecule mRNA increases in human umbilical vein endothelial cells (20) without exhibiting any agonist effects on these cells. Although this molecule has been characterized as an IL-1 receptor antagonist, further studies are necessary to investigate whether IL-1 ra has agonist effects on any target cells responsive to IL-1.

The biological relevance of IL-1 ra to normal physiology of IL-1, or to the possible role of IL-1 in pathophysiology, remains to be established. IL-1 ra binds to IL-1 receptors on T lymphocytes $(5,11,12)$, synovial cells and chondrocytes, ${ }^{2}$ but not to the second class of IL- 1 receptors that is present on a murine pre-B lymphocyte cell line $(12,21,22)$. As monocytes mature into macrophages, the cells produce less IL- 1 and more IL-1 ra $(23,24)$. IL-1 ra production by human macrophages is further stimulated by culture in granulocyte/macrophage colony-stimulating factor (GM-CSF) $(23,24)$. IL-1 ra may represent a natural receptor antagonist that limits the effects of IL-1 primarily in the microenvironment of tissue macrophages. IL-1 ra may be of therapeutic value in human diseases possibly mediated by pathophysiological effects of IL-1.

\section{Acknowledgments}

The excellent technical assistance of Brian Coll and expert secretarial assistance of Ms. Helen Martinez are gratefully acknowledged.

This work was supported by grants from the Rocky Mountain Chapter of the Arthritis Foundation, the Colorado Institute for Research in Biotechnology, the Helen K. and Arthur E. Johnson Foundation, the National Institutes of Health (AR-35805 and HL-29594) and Synergen, Inc.

\section{References}

1. Dinarello, C. A. 1989. Interleukin-1 and its biologically related cytokines. Adv. Immunol. 44:153-205.

2. Bendtzen, K., T. Mandrup-Poulsen, J. Nerup, J. H. Nielsen, C. A. Dinarello, and M. Svenson. 1986. Cytotoxicity of human $p \mathrm{I} 7$ interleukin-1 for pancreatic islets of Langerhans. Science (Wash. DC). 232:1545-1547.

3. Arend, W. P., and J.-M. Dayer. 1990. Cytokines and cytokine inhibitors or antagonists in rheumatoid arthritis. Arthritis Rheum. 33:305-315.

4. Larrick, J. W. 1989. Native interleukin 1 inhibitors. Immunol. Today. 10:61-66.

5. Arend, W. P., F. G. Joslin, R. C. Thompson, and C. H. Hannum. 1989. An IL-1 inhibitor from human monocytes: production and characterization of biologic properties. J. Immunol. 143:1851-1858.

2. Arend, W. P., and B. P. Coll. 1990. Interaction of recombinant human monocyte-derived interleukin-1 receptor antagonist with human synovial cells and rabbit articular chondrocytes. Submitted for publication.
6. Muchmore, A. V., and J. M. Decker. 1986. Uromodulin: an immunosuppressive 85-kilodalton glycoprotein isolated from human pregnancy urine is a high affinity ligand for recombinant interleukin-

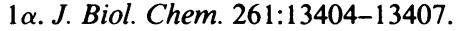

7. Rosenstreich, D. L., J. H. Tu, P. R. Kincade, I. Maurer-Fogy, J. Kahn, R. W. Barton, and P. R. Farina. 1988. A human urine-derived interleukin 1 inhibitor: homology with deoxyribonuclease I. J. Exp. Med. 168:1767-1779.

8. Arend, W. P., F. G. Joslin, and R. J. Massoni. 1985. Effects of immune complexes on production by human monocytes of interleukin 1 or interleukin 1 inhibitor. J. Immunol. 134:3868-3875.

9. Balavoine, J.-F., B. de Rochemonteix, K. Williamson, P. Seckinger, A. Cruchaud, and J.-M. Dayer. 1986. Prostaglandin $E_{2}$ and collagenase production by fibroblasts and synovial cells is regulated by urine-derived human interleukin 1 and inhibitor(s). J. Clin. Invest. 78:1120-1124.

10. Seckinger, P., K. Williamson, J.-F. Balavoine, B. Mach, G. Mazzei, A. Shaw, and J.-M. Dayer. 1987. A urine inhibitor of interleukin 1 activity affects both interleukin $1 \alpha$ and $1 \beta$ but not tumor necrosis factor $\alpha$. J. Immunol. 139:1541-1545.

11. Seckinger, P., J. W. Lowenthal, K. Williamson, J.-M. Dayer, and H. R. MacDonald. 1987. A urine inhibitor of interleukin 1 activity that blocks ligand binding. J. Immunol. 139:1546-1549.

12. Hannum, C. H., C. J. Wilcox, W. P. Arend, F. G. Joslin, D. J. Dripps, P. L. Heimdal, L. G. Armes, A. Sommer, S. P. Eisenberg, and R. C. Thompson. 1990. Interleukin-1 receptor antagonist activity of a human interleukin-1 inhibitor. Nature (Lond.). 343:336-340.

13. Eisenberg, S. P., R. J. Evans, W. P. Arend, E. Verderber, M. T. Brewer. C. H. Hannum, and R. C. Thompson. 1990. Primary structure and functional expression from complementary DNA of a human interleukin-1 receptor antagonist. Nature (Lond.). 343:341-346.

14. Mosmann, T. 1983. Rapid colorimetric assay for cellular growth and survival: application to proliferation and cytotoxicity assays. J. Immunol. Methods 65:55-63.

15. Dayer, J.-M., S. M. Krane, R. G. G. Russell, and D. R. Robinson. 1976. Production of collagenase and prostaglandins by isolated adherent rheumatoid synovial cells. Proc. Natl. Acad. Sci. USA. 73:945-949.

16. Arend, W. P., F. G. Joslin, and R. J. Massoni. 1985. Characteristics of chondrocyte responses to a human interleukin 1-like factor. Clin. Immunol. Immunopathol. 36:358-370.

17. Westcott, J. Y., S. Chang, M. Balazy, D. D. Stene, P. Pradelles, J. Maclouf, N. F. Voelkel, and R. C. Murphy. 1986. Analysis of 6-keto $\mathrm{PFG}_{1 \alpha}, 5$-HETE, and $\mathrm{LTC}_{4}$ in rat lung: comparison of GC/MS, RIA and EIA. Prostaglandins. 32:857-873.

18. Cooper, T. W., E. A. Bauer, and A. Z. Eisen. 1982. Enzymelinked immunosorbent assay for human skin collagenase. Collagen Relat. Res. 3:205-216.

19. Welgus, H. G., and G. P. Stricklin. 1983. Human skin fibroblast collagenase inhibitor: comparative studies in human connective tissues, serum, and amniotic fluid. J. Biol. Chem. 258:12259-12264.

20. Eisenberg, S. P., R. C. Thompson, and G. N. Cox. 1989. An interleukin-1 inhibitor (IL-1i) blocks IL-1 induced adhesion of neutrophils to endothelial cells. Cytokine. 1:90. (Abstr.)

21. Chizzonite, R., T. Truitt, P. L. Kilian, A. S. Stern, P. Nunes, K. P. Parker, K. L. Kaffka, A. O. Chua, D. K. Lugg, and U. Gubler. 1989. Two high-affinity interleukin 1 receptors represent separate gene products. Proc. Natl. Acad. Sci. USA. 86:8029-8033.

22. Bomsztyk, K., J. E. Sims, T. H. Stanton, J. Slack, C. J. McMahan, M. A. Valentine, and S. K. Dower. 1989. Evidence for different interleukin-1 receptors in murine B- and T-cell lines. Proc. Natl. Acad. Sci. USA. 86:8034-8038.

23. Roux-Lombard, P., C. Modoux, and J.-M. Dayer. 1989. Production of interleukin-1 (IL-1) and a specific IL-1 inhibitor during human monocyte-macrophage differentiation: influence of GM-CSF. Cytokine. 1:45-51.

24. Janson, R. W., and W. P. Arend. 1989. The effects of GM-CSF on IL-1 $\beta$ and IL-1 inhibitor (IL-1i) production in human in vitro-derived macrophages. Cytokine. 1:91. (Abstr.) 